\title{
Swedish firm in recombinant DNA storm
}

RECOMBINANT-DNA research in private firms in Sweden has got off to a very shaky start. The only firm to have applied to use the technique is threatening to move abroad if permission to go ahead is not given.

The firm concerned, KabiGen $\mathrm{AB}$, is half owned by the state pharmaceutical company Kabi Vitrum, and half by private interests. It was set up in 1968 to investigate new sources of raw materials for Kabi Vitrum and is currently researching the production of human growth hormone by recombinant DNA techniques. Recently, the firm applied to the Hybrid-DNA Committee for permission to go ahead with further development. Permission was given to carry out the work P3/EK1 or P2/EK2 conditions under the revised NIH guidelines.

Kabigen already had a virology laboratory nominally between P3 and P4 standards; but as there were small parts of it which could collect dust, the firm announced that it would rebuild it. But an article in a Stockholm daily paper, written by the chairman of the Centre Party organisation in the same area as KabiGen, was very critical of the firm's plans to build the laboratory, especially as it is in a densely-populated part of Stockholm, and demanded that nothing be done until the whole issue had been debated publicly.

KabiGen's director, Dr Bertil Aberg, said that the firm's existence hinged on the laboratory being built and that the research would be moved abroad if the local health and building authorities did not approve the proposed changes and give permission for recombinant-DNA work to be done there.

The Centre Party - the carrier of the
Swedish anti-nuclear banner - drew a parallel between the two issues, saying that unless there is a public debate now, recombinant-DNA research would become the nuclear debate of the 1980s. But the Party had not checked its facts. While claiming that KabiGen was proposing to build a "high risk labortory ... . without counterpart in Sweden", it was evidently unaware that there are already 25 P3 laboratories within a five-mile radius of Stockholm, handling dangerous pathogens in the State Bacteriological Institute and in local hospitals. It is doubtful, too, whether making minor alterations in the existing laboratory could be called "building". In spite of this, Dr Aberg seems to regret his initial openness. "KabiGen is the only industry using recombinant-DNA techniques", he told Nature. "Universities are doing a great deal of work with them, but they are very wisely keeping quiet about it."

However, this is not strictly true. All universities and private industries have agreed to inform the Hybrid-DNA Committee, set up in 1975 under the Natural Sciences Research Council, of any recombinant-DNA research they want to do. The committee then advises them about security levels. However this system will shortly be changed, if a bill proposed by the previous Liberal government is passed by the new Liberal-CentreConservative coalition. The bill is based on a one-man investigation of whether recombinant-DNA research can be carried out under Sweden's present laws. It proposed that a new body, to be called the Biotechnical Committee, be set up under the present Labour Protection Board, to advise the Board whether specific experiments may be done and under what conditions. It would also follow international events in the field and keep the Board, government and public informed of developments.

According to the Bill, the committee should be composed of specialists in genetics, microbiology, biochemistry and plant breeding; representatives of the Social Welfare Board, Nature Protection Agency, relevant research councils, trades unions and employers' federations. The chairman of the committee should be the Director of the Labour Protection Board. The bill does not specify exactly how many members the Committee should have; but the report on which it is based suggested a composition which put the scientists in the minority. Until a decision on the new system can be taken, there is a moratorium on new recombinant-DNA work.

Predictably, many members of the Present Hybrid-DNA Committee (which has eleven members: seven scientists, one research engineer, one laboratory assistant and two Members of Parliament) are very critical of the proposed system. Professor Peter Reichard, the Chairman of the present committee, told Nature cautiously that "the new system won't be better than the present one." Other scientists were more forthright. "The new system would be enormously dangerous", declared Professor Lennart Philipson of Uppsala University. "It would be very bureaucratic: totally impossible. How much should you let public opinion aroused by newspapers influence the work of governmental agencies? Everything will depend on the people on the committee. How much common sense will they have?"

Wendy Barnaby

\section{Avowed Nazis attack Brazilian physicists}

A group calling itself the Movement for Nazi Renovation (MRN) has physically attacked scientists and intellectuals in Brazil. In a letter sent to the press they "take the responsibility for the terrorist attack upon the house of Mario Schemberg and his wife Lourdes Cedran". Schemberg is President of the Brazilian Physical Society; his wife was beaten up last month at her home by two men. At the same time several other jewish physicists and artists received anonymous telephone calls.

The MRN criticised these people, some "for having international prestige, for being jewish and as such diabolic", and others "for being living filth and all against the nuclear agreement" (between Brazil and Germany). The MRN also declared itself "against the feminist movement which, although pure nonsense, stimulates women to disobey men and have ideas of their own." The letter proclaims that MRN is "in favor of the nuclear agreement and of the arian race reassuming its historical role, specially in the military domain."

"The situation is quite serious", Professor Jacques Danon of the Brazilian Centre for Physics Research in Rio declared in a manifesto signed by all members of the centre: "A professor of sociology from Campinas was abducted last week and forced to drink castor oil ... What is most worrysome is that the government is trying to minimize these terrorist attacks."

The head of the Security Police of Sao Paulo declared that one should not be concerned about "a joke done in bad taste", while the influential ex-minister of education Passarinho declared that the whole "affair" was unimportant.

The scientific community is apprehensive. The end of formal political repression had indeed led to open criticism of Brazil's gigantic nuclear agreement with West Germany which involves the construction of eight $1000 \mathrm{MW}$ nuclear power stations in the next five years
(Nature 2 August 79). The physicists presently under attack have all been particularly vehement in their opposition to the government's nuclear option for Brazil.

Recently Professor Cerqueira Leite said that the president of Nuclearbras, the government company which administers the nuclear contract, had gone from being a "nuclearcrat" to being a "nuclearpath" in accusing the physicists of participating in an international conspiracy against Brazilian interests allegedly involving both the United States and the Soviet Union.

The scientists are demanding in their manifesto that the authorities take the situation seriously. In the words of professor Danon, "even if MRN consists of a few crazy individuals, the government must prove that it has the will to act against them; otherwise some of our colleagues will be found dead tomorrow."

Maurice Bazin 